\title{
Development of Machining Technology Material by Using Teaching Factory Based on Metacognitive Skill Model
}

\author{
Selamat Riadi ${ }^{1}$, Selamat Triono $^{2}$, Muslim $^{3}$ and Syahril ${ }^{4}$ \\ \{selamatriadi.unimed@gmail.com\} \\ Universitas Negeri Medan, Jurusan Pendidikan Teknik Mesin, Medan ${ }^{1,2,3}$, Universitas Negeri Padang, \\ Jurusan Pendidikan Teknik Mesin ${ }^{4}$
}

\begin{abstract}
This research is to develop learning material of machining technology with Teaching Factory Model approach based on metacognitive skill on Mechanical Engineering Education in Universitas Negeri Medan. The method used in research and development is development design of ADDIE. The results show that machinery technology lecture with Teaching Factory Model approach based on metacognitive skill is proper to be used with practicability level reach to $80.39 \%$, and it is effective because resulting significant differentiation of study result value between experimental class and control class based on result of $t$ experimental with value of $t_{\text {arithmetic }}=2.72$ and $t_{\text {table }}=2.021$. Thus, Machining Technology Textbook by using Teaching Factory Based on Metacognitive Skill Model can be used practically and effectively in the learning process.
\end{abstract}

Keywords: Learning Lecture, Machining Technology, TEFA-BMS.

\section{Introduction}

In industry revolution era 4.0, disruption is keyword that always be prioritized and watch out for, because it contains indictment purpose that education task and coaching is to prepare human who has capability to think, creatively in attitude and doing for facing unpredictable alteration as planning annoyance. There is seven of survival skill needed in education for facing the changing of "Old World" of classrooms in the "New World" of work. However from the skill, critical thinking and problem solving skill with reinforcement on adaptability power is fundamental competency as way of life in $21 \mathrm{~s}$. It is caused of the new world arrangement with characteristic economy knowledge-based indicate that every activities always expressed in; tasks, or problem, or final goal should be finished. Nevertheless, critical thinking and problem solving is important skill for all workers in industry society. Thus, implementation of learning model for graduation should have the competency as a basic of self-development.

Teaching Factory Based on Metacognitive Skill $=T E F A-B M S[1]$ as one of learning model development with some purposes; Outputting professional graduation in their filed, develop modern curriculum, effectively solution of demonstration in facing industry challenges, transfer of technology from industry by being education institution partner [2]. The development of teaching factory in Penn State University, The University of Puerto Rico-Mayaguez, The University of Washington, and Sandia National Labs is to give real experience in design, manufacture, and realization product designed, then curriculum development balance between theory skill and manufacture analysis, design, business activity, and professional skill [3]. The 
image of ideal cooperation between education institutes with industry institute ideal that concern and benefit one each other can be shown as fig. 1 [4]:

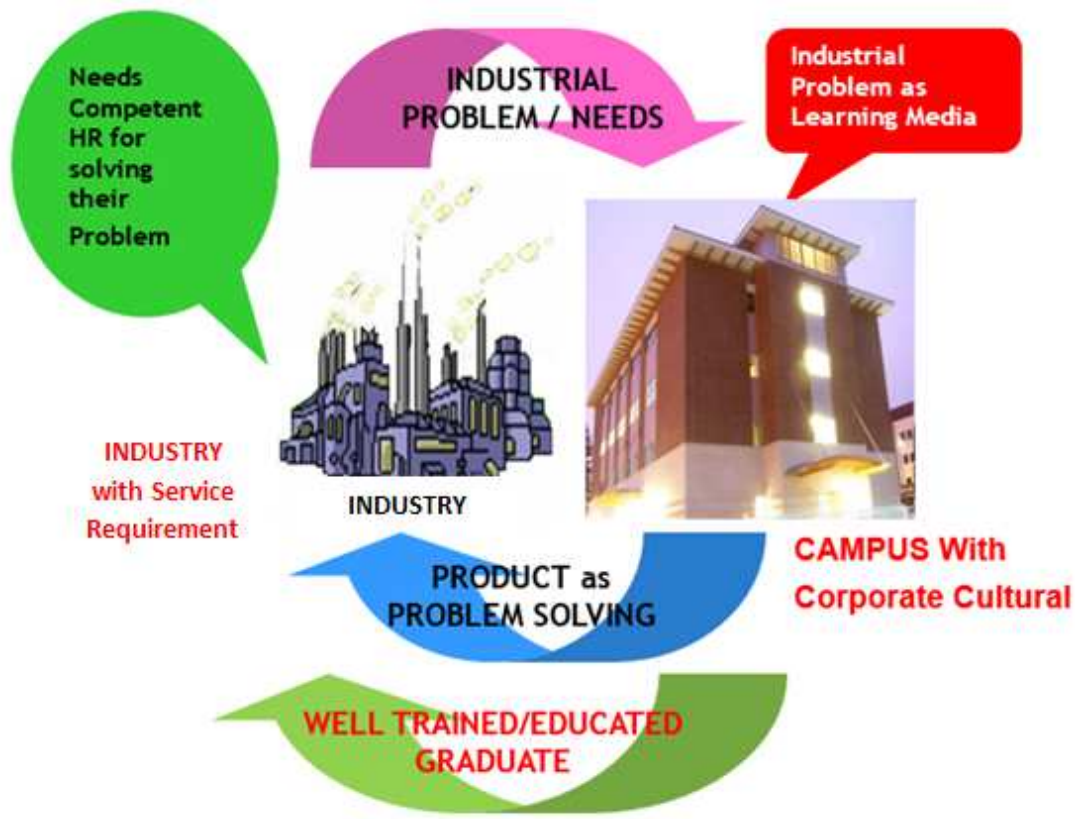

Fig. 1. Education cooperation and industry model

The implementation is in the education institute, a concept that converse education mode becomes a challenge place for student in attaining experience, development of responsibility, accountability, attitude, knowledge and skill for their contribution to society one day [5]. Schematically, the concept of learning Teaching Factory shown in fig. 2:

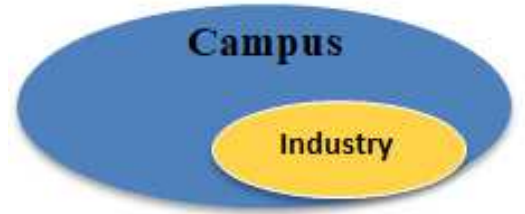

Fig. 2. Scheme of Teaching Factory Concept

In learning model implementation, the utilization of learning lecture is a urgent completeness because candidate of student SMK teacher candidate who will become main education doer in the future should be supplied by learning lecture approach model that appropriate with their skill characteristic, because if it is not, then their expectation for being able to teach student effectively and efficiently will not be true. 


\section{Method}

This research is a development research with the objective to produce a product like learning lecture of machinery technology by using design and development of ADDIE [7], the steps shown as fig. 3:

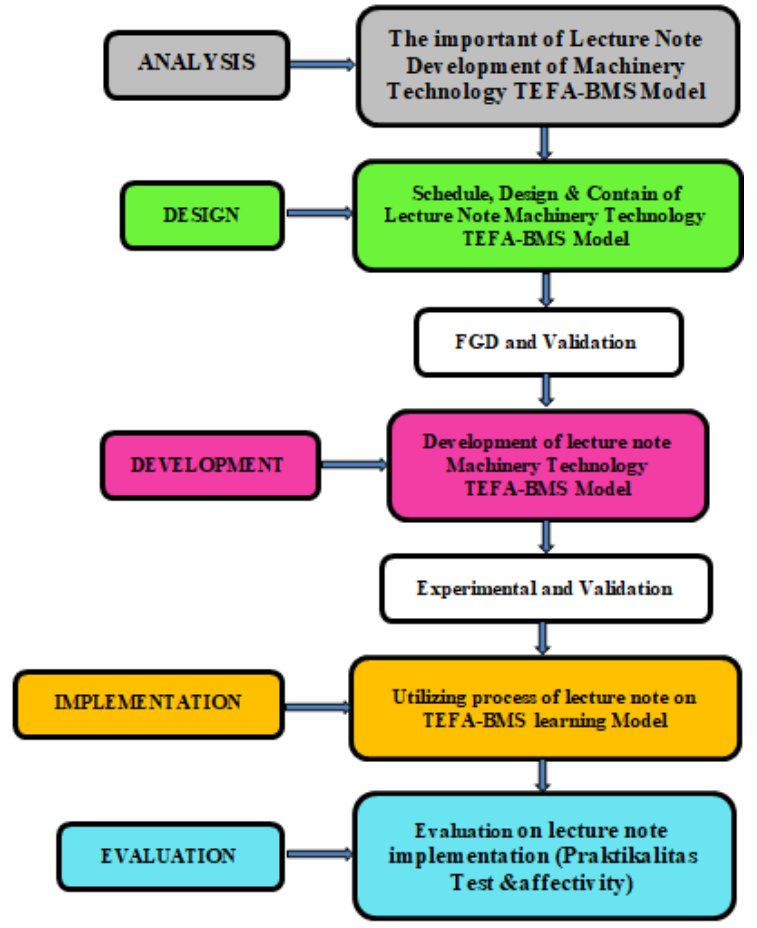

Fig. 3. Scheme of research steps

\section{Result and Discussion}

The results of engine development technology with TEFA-BMS Model are validated by five validators as their expertise. Result of review or validation concerned by machinery technology analyzed by using Aiken's V formula and the recapitulation can be shown in Table 1.

Table 1. Summary of assessment Validator to Contain of Lecture

\begin{tabular}{lcccc}
\hline $\begin{array}{c}\text { Added Value } \\
\text { Aspect }\end{array}$ & $\begin{array}{c}\boldsymbol{\Sigma} \text { Validator } \\
(\mathbf{1 - 5})\end{array}$ & $\mathbf{\Sigma S}$ & $\begin{array}{c}\text { Distance of calculation } \\
\text { result (Aiken's V } \\
\text { Formula) }\end{array}$ & Explanation \\
\hline Item 1-31 & 631 & 476 & $0,65-0,90$ & Valid \\
Average & $\mathbf{2 0 , 3 5}$ & $\mathbf{1 5 , 3 5}$ & $\mathbf{0 , 7 7}$ & Valid \\
\hline
\end{tabular}

Based on data analysis on Table 1 shows that validation from book contain of machinery technology with TEFA-BMS model include some aspects and indicator; (a) organization 
lecture, (b) Process of writing, (c) contain, and (d) language. Result of statistic data shows Aikens'V average value 0.77 with interval Aikens'V range 0 to 1 . An assessment will be valid with Aikens'V criteria value above 0.60 then it is valid [1]. That is why, validation result from expert team about lecturing got 0.77 means more than $>0.60$, thus it is valid category. Nevertheless, in lecture note contains some suggestion can be used to enhance the contain quality.

\section{Practicality Test from Machinery Technology Lecture note by Lecturer}

In measuring practicability from machinery technology lecture note with TEFA-BMS model from its praktikalitas side implicate some aspect; (a) presentation, (b) compatibility, (c) expediency, and (d) language with total 19 indicators. Assessment done by giving number between 1 (not represent or not relevant) until 5 (represent or very relevant). Aiken's V statistic can be expressed by [1]:

$\mathrm{V}=\frac{\sum \mathrm{S}}{\mathrm{n}(\mathrm{c}-1)}$

given:

$\mathrm{S} \quad=\mathrm{r}-\mathrm{lo}$

lo $\quad=$ Number of low validity (in this case $=1$ )

c $\quad=$ Number of high validity (in this case $=5$ )

The resume of practicality test from lecture note of TEFA-BMS Model shown in Table 2:

Table 2. Result of practicality test of lecture note machinery technology in TEFA-BMS learning model

\begin{tabular}{cccc}
\hline Assessment Value & Assessment Range & \% Practicality & Desc. \\
\hline Indicator 1 - 19 & $3,5-4,75$ & $70-95$ & \\
Average Value & $\mathbf{4 , 0 2}$ & $\mathbf{8 0 , 3 9}$ & Very Practical \\
\hline
\end{tabular}

In practicability instrument model and product, the data got from observation assessment from lecturer respond although students. The questionnaire assessment based on model or products from experimental. Rejoinder score from each criterion done by descriptive analysis. Based on practicality test by lecturer about lecture note of machinery technology with TEFABMS model generally expressed by "Very Practical" with P range value (mean) from 3,50 to 4,75 or $70 \%-95 \%$ (Mean $80,39 \%$ )

\section{Affectivity test from lecture note of machinery technology to students}

The affectivity level of lecture note developed from student learning output as experimental and control class. Differentiation analysis done by using t-test formula as shown; Arithmetic formula:

$$
t_{\text {count }}=\frac{M Y 1-M Y 2}{\sqrt{\frac{S S 1+S S 2}{n 1+n 2-2}\left(\frac{1}{n 1}+\frac{1}{n 2}\right)}}
$$

Where: 
$\mathrm{MY}_{1}=\frac{\Sigma Y_{1}}{n_{1}}=\frac{1695}{20}=84,75$

$\mathrm{MY}_{2}=\frac{\Sigma Y_{2}}{n_{2}}=\frac{1758}{22}=79,91$

$\mathrm{SS}_{1}=\Sigma Y_{1}^{2}-\frac{\left(\Sigma Y_{1}\right)^{2}}{n_{1}}=144227-\frac{(1695)^{2}}{20}=575,75$

$\mathrm{SS}_{2}=\Sigma Y_{2}^{2}-\frac{\left(\Sigma Y_{2}\right)^{2}}{n_{2}}=141226-\frac{(1758)^{2}}{22}=745,82$

Thus: $t_{\text {count }}=\frac{84,75-79,91}{\sqrt{\frac{575,75+745,82}{(20+22)-2}\left(\frac{1}{20}+\frac{1}{22}\right)}}=2,72$

In this experimental using significance degree $\alpha=0,05$ with degree of freedom $(\mathrm{df})=\left(\mathrm{n}_{1}\right.$ $\left.+\mathrm{n}_{2}-2\right)=40$, then from Statistic Table got $t_{\text {table }}=2,021$. From accounting comparison can be expressed that $t_{\text {arithmetic }}=2,72>t_{\text {table }}=2,021$, It means that the average value of experimental and control class is different significantly.

Table 3. Resume of Affectivity Test of Machinery Technology Lecture Note on TEFABMS Learning Model

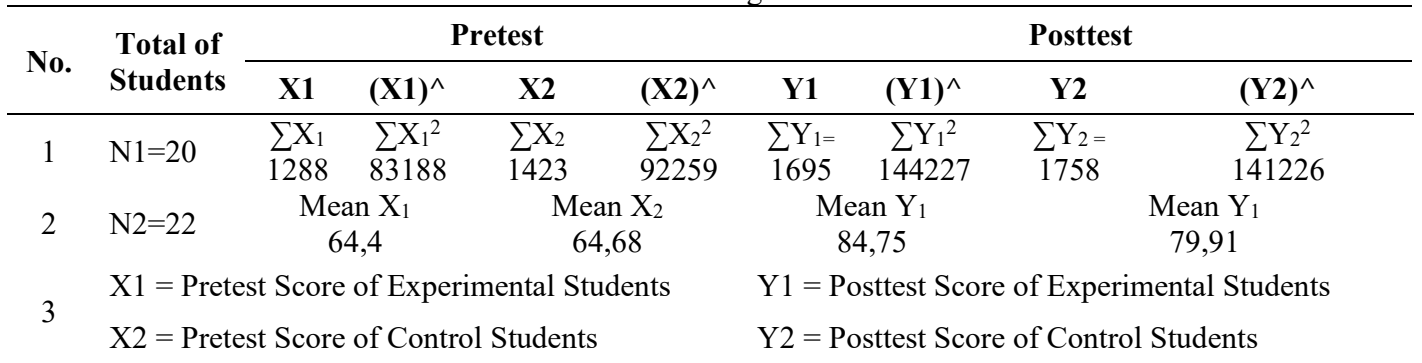

Comparison of assessment result tarithmetic $=2,72>$ table $=2,021$, means that average value of experiment and control class is significantly different

\section{Research Discussion}

The findings of the research development in this learning material show that teaching materials developed are included in the Valid, Very Practical, and Effective categories. It can be interpreted that the developed teaching material has been able to be a differentiating factor in the effort to achieve learning outcomes in Machining Technology with the TEFA-BMS learning model approach so that the teaching material products developed can be used for learning of Machining Technology well. Many research results about lecture note recommend that the use of lecture note in the learning process is very important and one of the factors determine learning outcomes including in Jakarta, [10] [11] in Palembang. The result of a research that student learning outcomes using printed textbooks were higher in learning outcomes compared to using digital textbooks [13]. Student learning outcomes for those who use printed books (hardcopy) were significantly higher than students who used textbook based on web (e-textbook) [14].

Based on the results of the research above, it is highly recommended that each learning instructor be able to develop and use textbooks in designing and conducting learning. Specifically for learning Machining Technology, because the specifications require that learning outcomes not only be skilled in the psychomotor field but also based on a fundamental cognitive foundation, strong, wide and visceral, the provision of lecture note is a prerequisite in the 
learning process. Even though open teaching material in cyberspace is widely available, the research results reveal that students prefer and appear better when reading on screen, but their actual performance disposed to suffer [14]. In addition, other findings suggest that students can better understand information for textbook is more than one page in printed form than in digital/screen form. Learning in taking note is important skill that will be needed by students who will continue their study at university while with the advancement of digital material fewer students learn to take notes [15]. Besides learning in textbooks will be better to remember the title of the book even students can remember every page and diagram in the text.

\section{Conclusion}

Based on the result of experimental and discussion, the conclusion is as follows:

1. Learning material of machinery technology developed is reasonable to be used in learning process with teaching factory model approach based on Metacognitive Skill.

2. Learning material of machinery technology developed is effective to be used in learning process with teaching factory model approach based on Metacognitive Skill.

Afterward, the implication of research conclusion can be suggested as follows:

1. Every lecturer advisable completing learning process in order to prepare lecture note to reach maximal learning process

2. Lecture note of machining technology with Teaching Factory model approach based on Metacognitive Skill is needed to be developed as machinery technology development and developing lecture.

\section{References}

[1] Riadi, S. et al. Effectiveness of Metacognitive Learning's Model in Engineering. www.ijeat.org (2019).

[2] Azwar, S. Reliabilitas dan Validitas. Yogyakarta: Pustaka Pelajar (2013).

[3] Joachim, et.al. Learning Factories for research, education, and training. Procedia CIRP 32 (2015).

[4] Moerwismadhi. Teaching Factory Suatu Pendekatan dalam Pendidikan Vokasi yang Memberikan Pengalaman ke Arah Pengembangan Technopreneurship. https://www.slideshare.net/flatburger/tl-for-teaching-factory-malang (2009).

[5] Dadang, HM. Developing a Teaching Factory Learning Model To Improve Production Competencies Among Mechanical Engineering Students in a Vocational Senior High School. Journal of Technical Education and Training (JTET) (2012).

[6] Fike, David. Et al. Do E-Textbooks Impact Learning Outcomes?. https://www. researchgate.net/ publication/325324690 (2016).

[7] Harsono, Y.M. Developing Learning Materials for Spesific Purposes. TEFLIN Journal, Volume 18, Number 2, August 2007. Jakarta (2007).

[8] Kurt, S. ADDIE Model: Instructional Design in Educational Technology. Retrieved from https://educationaltechnology.net/the-addie-model-instructional-design/ (2017). 
[9] Nopriadi dkk. Pengambangan Bahan Ajar Berbasis Modul Elektronik pada Mata Kuliah Konstruksi Bodi Kenderaan pada Program Studi Pendidikan Teknik Mesin Universitas Sriwijaya. Jurnal Teknik Mesin. Vol.3 No.2. Palembang (2016).

[10] Prasetya, S.P. The Effect of Textbooks on Learning Outcome Viewed from Different Learning Motivation. 1st International Conference on Education Innovation (ICEI). Advances in Social Science, Education and Humanities Research, Volume 173 (2017).

[11] Solichin, dkk. Pengembangan Bahan Ajar Mata Kuliah Praktikum Pengelasan. Jurnal Teknik Mesin. Tahun 21.No.1 April 2013: Malang (2013).

[12] Alptekin, Sema E. Teaching Factory. Proceedings of the 2001 American Society for Engineering Education Annual Conference \& Exposition (2011).

[13] Tony Wagner. The Global Achievement Gap. http://www.tonywagner.com/271. Accessed on December (2016).

[14] World Economic Forum. Students Learn Better from Books than Screens, According to a New Study. https://www.weforum.org/agenda/2017/10/students-learn-better-from-booksthan-screens-according-to-a-new-study (2017).

[15] Lenon, Barnaby. Textbooks Have a Huge Impact on Education. https://www.telegraph. co.uk/education/educationopinion/11739310/Textbooks-have-a-huge-impact-oneducation.html (2019). 